Asian-Australasian Journal of Food Safety and Security ISSN 2523-1073 (Print) 2523-2983 (Online) www.ebupress.com/journal/aajfss

\title{
Article
}

\section{Microbiological quality assessment and acceptance of dairy products in Dhaka city}

\author{
Md. Nur Hossain ${ }^{1}$, Sanjida Humayun ${ }^{1}$, Md. Zahurul Haque ${ }^{2}$ and Monzur Morshed Ahmed ${ }^{1}$ \\ ${ }^{1}$ Industrial Microbiology Laboratory, Institute of Food Science and Technology (IFST), BCSIR, Dhanmondi, \\ Dhaka-1205, Bangladesh \\ ${ }^{2}$ Director, Institute of Food Science and Technology (IFST), BCSIR, Dhanmondi, Dhaka-1205, Bangladesh
}

*Corresponding author: Md. Nur Hossain, Senior Scientific Officer, Institute of Food Science and Technology (IFST), BCSIR, Dhanmondi, Dhaka-1205, Bangladesh. Phone: +8801717625372; E-mail: mnhossain84@gmail.com, mnhossain84@ifstbcsir.gov.bd

Received: 07 November 2017/Accepted: 21 November 2017/ Published: 21 November 2017

\begin{abstract}
This investigation was carried out to evaluate the microbiological quality of the processed dairy products including borhani, matha/labang, sweet \& sour yoghurt. Dairy products are consumed as desert and popular enough among the people. 50 of the different dairy samples were collected from street vendor and also from some branded shop in Dhaka city. The microbiological quality of the samples were analyzed and monitored according to criteria in European Commission Recommendations 2004/24/EC and 2005/175/EC, BSTI and USPHS. All the dairy products had high microbial load ranged $5.90 \times 10^{5} \mathrm{cfu} / \mathrm{ml}$ to $8.97 \times 10^{9} \mathrm{cfu} / \mathrm{ml}$. Coliforms were found up to $10^{9}$ dilutions in milk based drink products Borhani and Labang considered a serious threat to the public health. The mold contamination was much lower in Borhani and Labang compared to yoghurt $7.86 \times 10^{8} \mathrm{cfu} / \mathrm{ml}$. Approximately $17 \%$ dairy products were contaminated by Salmonella spp. Majority of the dairy products $(25.537 \%$,) such as Yogurt, Borhani and Labang were contaminated by Staphylococcus spp. The presence of Listeria monocytogenes found in Yogurt, 7 out of $21(21.515 \%)$ samples were contaminated. A minor number of milk based products were corrupted by Shigella spp. These results emphasize applying and maintaining good hygiene practices throughout the processing chain to prevent contamination and bacterial growth. It was concluded that the presence of some pathogens in milk based products with toxigenicity of some strains pose a health hazard to consumers. Thus, good hygienic practices, good manufacturing practices, HACCP with all other hygienic practices should be applied during processing and distribution for public health safety.
\end{abstract}

Keywords: dairy products; microbial quality; assessment; acceptance

\section{Introduction}

Now a days, one of the biggest economic problem is food spoilage, approximately one fourth of food around the world is spoiled by microbiological activity which is thought to be most significant medium of foodborne disease mainly caused by the lack of knowledge about food safety and sanitation, transmitting around the world (Huisin't Veld, 1996; WHO, 1999) and also have been the reason of high mortality and morbidity in all over Bangladesh for years (Haq and Rahman,1991; Henry et al., 1990; Islam et al., 1993; Luby et al., 2006; Ram et al., 2007; Saha et al., 2009; Sheikh et al., 2002). Milk is thinks of perfect, complete and one of the most nutritious foods for all aged people from child to old contains minerals along with calcium these are required bone growth and maintenance (Aneja et al., 2002), despite that milk can be used as potential growth media for organisms which is full of nutrients that enhance the rate of duplication and production of toxin by microorganisms (Ruegg, 2003; Rajagopal et al., 2005). A variety of organisms that can cause spoilage of milk products include some lactic acid bacteria, Gram negative bacteria, coliforms, yeast and fungus in addition some pathogenic bacteria like Listeria monocytogenes, Salmonella spp., Campylobacter jejuni, Escherichia coli and 
toxic strains of Staphylococcus aureus also found in milk products (Tatini and Kauppi, 2003). Consummation of dairy products or milk contaminated by pathogens or toxic metabolites can lead to food borne infection and poisoning interestingly, few endotoxin pathogenic bacteria undergo lysis and release toxic metabolites in intestinal tract can lead to septic shock (Aneja et al., 2002). These pathogens may directly or indirectly enter in milk and milk products which serves as complex biochemical composition and high water activity, milk and milk products serve as an excellent medium for the growth and replication of organisms during handling, processing, pre and post heat treatment, packaging etc. (Richter et al., 1992). That is why microbiological analyses are crucial food safety, security, quality and conformation with standards and specifications (Vasavada, 1993). Most of the dairy products are produce in traditional manner by unpasteurized raw milk without consideration of nutritional and microbiological standards of the raw materials, which allows many bacteria to grow which can change the products flavor, color, consistency and odor. These incidences are decreased in half by Quality and safety management systems such as ISO and Hazard Analysis Critical Control Point (HACCP). In addition, Bangladesh Standard Testing Institution also working to improve the physical, chemical and microbiological quality of milk and dairy products to reach the acceptable quality ofwhich would be safe for consumption. The indicator bacteria and some other organisms in dairy products are now used to determining the safety and quality of milkand milk products (Uddin et al., 2011). To reduce economic losses by the early detection of insufficient processing, packaging or refrigeration, microbiological assessments play an important role to in the dairy industry. The purpose of this study is to determine the microbiological quality and cause food-borne pathogens such as coliform, L. monocytogenes, Staphylococcus spp., Salmonella spp. and Shigella spp. of dairy product samples collected from various points of Dhaka city and identify the sources of contamination along with possible solution.

\section{Materials and Methods}

\subsection{Study location and length of study}

For this study all the experiments were conducted in Industrial Microbiology Lab, IFST, Bangladesh Council of Scientific and Industrial Research (BCSIR Laboratories, Dhaka) from February 2017 to July 2017.

\subsection{Sample collection}

Fifty different types dairy products such as Labang, Sweet Yogurt, Sour Yogurt and Borhani were collected from fifty street food vendors and local shops situated in various points of Dhaka city. Approximately $500 \mathrm{ml} / 200 \mathrm{~g}$ samples were taken aseptically in separate screw-capped wide mouthed plastic containers/polythene bag then kept at $4^{\circ} \mathrm{C}$ in a sample collector box and were immediately transported to the laboratory for the analysis of several microbiological parameters, if laboratory analysis was delayed due to the delayed arrival of samples, those samples were refrigerated at $0-4{ }^{\circ} \mathrm{C}$ until examination but not longer than 48 hours.

\subsection{Microbiological culture method}

\subsubsection{Culture method of total plate count}

$25 \mathrm{ml} / \mathrm{g}$ of each milk product samples were weighted and aseptically added in $225 \mathrm{ml}$ of sterile Peptone Water $\left(\mathrm{Difco}^{\mathrm{TM}}\right.$ ) then homogenized the mixture in a blender at $600 \mathrm{rpm}$ for $10-15 \mathrm{~min}$ and diluted up to $10^{-10}$ times. The total viable bacterial count was carried out by the spread plate technique (ISO 4833:2003). The diluted sample $(1 \mathrm{ml})$ of each dilution were inoculated into Plate Count Agar (Difco ${ }^{\mathrm{TM}}$ ) for Total Viable Bacterial Count (TVBC) using pour plate technique (Marjan et al., 2014). The plates were screened for the presence of discrete colonies after incubation period and the actual numbers of bacteria were estimated as colony forming unit in per $\mathrm{ml}(\mathrm{cfu} / \mathrm{ml})$. Quantitative analysis for the presence or absence of specific microorganisms was done by plating on selective media.

\subsubsection{Culture method of coliform and $E$. coli}

$10 \mathrm{ml}, 1 \mathrm{ml}$ and $0.1 \mathrm{ml}$ of sample to $3 / 5$ tubes of LST for each amount. LST tubes were incubated at $35^{\circ} \mathrm{C}$. Tubes were examined and record reactions at $24 \pm 2 \mathrm{~h}$ for gas, i.e., displacement of medium in fermentation vial or effervescence when tubes are gently agitated. Re-incubated gas-negative tubes for an additional $24 \mathrm{~h}$ and examine and record reactions again at $48 \pm 2 \mathrm{~h}$. and confirmed test on all presumptive positive (gas) tubes (ISO 4831:2006. and ISO 7251:2009. Geneva). From each gassing LST tube, transfer a loopful of suspension to a tube of BGLB broth, voiding pellicle if present. Incubated BGLB tubes at $35^{\circ} \mathrm{C}$ and examine for gas production at $48 \pm 2 \mathrm{~h}$. If gas-positive BGLB tube showed a pellicle, perform Gram stain to ensure that gas production was not due to Gram-positive, lactose-fermenting bacilli. Calculation was done by most probable number (MPN) of 
coliforms based on proportion of confirmed gassing LST tubes for 3 consecutive dilutions. $10 \mathrm{ml}, 1 \mathrm{ml}$ and 0.1 $\mathrm{ml}$ of sample were added to 3 tubes of LST-MUG for each amount. LST tubes were incubated at $35^{\circ} \mathrm{C}$. Examine tubes and record reactions at $24 \pm 2 \mathrm{~h}$ for gas. Gas-negative tubes were re-incubate for an additional $24 \mathrm{~h}$ and examine and record reactions again at $48 \pm 2 \mathrm{~h}$. Confirm test was performed on all presumptive positive (gas) tubes. Both positive and negative tubes were incubated for 24 to $48 \pm 2 \mathrm{~h}$ at $35^{\circ} \mathrm{C}$. Examine each tube for growth (turbidity, gas) then examine tubes in the dark under UV long-wave lamp $(365 \mathrm{~nm})$. A bluish fluorescence is a positive presumptive test for E. coli. From each gassing LST tube of the Presumptive test, transfer a loop-full of the suspension to a tube containing EC broth. EC tubes $24 \pm 2 \mathrm{~h}$ at $44.5^{\circ} \mathrm{C}$ were incubated and examine for gas production. The Completed test for $E$. coli was performed, gently agitate each gassing EC tube and streak for isolation, a loop-full to an EMB agar plate and incubate $18-24 \mathrm{~h}$ at $35^{\circ} \mathrm{C}$. Plates for suspicious E. coli colonies were examined, i.e., dark centered and flat, with or without metallic sheen. Up to 5 suspicious colonies were transferred from each EMB plate to PCA slants and incubate for $18-24 \mathrm{~h}$ at $35^{\circ} \mathrm{C}$ and use for further testing. Identification of any 1 of the 5 colonies as $E$. coli is sufficient to regard that EC tube as positive; hence, not all 5 isolates may need to be tested.

\subsubsection{Culture method of Salmonella spp. and Shigella spp.}

$25 \mathrm{gm}$ of sample was added in $225 \mathrm{ml}$ of Buffered peptone water and incubate at $37^{\circ} \mathrm{C}$ for $18 \pm 2 \mathrm{~h}$ (ISO 6579:2002-1:2007 and ISO 21567:2004, Geneva). Then the pre-enriched culture was incubated in Modified semi-solid Rappaport-Vassiliadis agar plate at $41.5^{\circ} \mathrm{C}$ for $24 \pm 2 \mathrm{~h}$. the enriched culture then inoculated in xylose lysine deoxycholate agar or any other solid selective medium complementary to XLD agar. The presumptive salmonella colonies were confirmed by means of appropriate biochemical and serological tests.

\subsubsection{Culture method of Staphylococcus spp.}

$25 \mathrm{~g}$ Sample stomatched in $225 \mathrm{ml}$ Phosphate Buffered Saline/Alkaline Peptone Water Prepare serial dilutions by transferring $1 \mathrm{ml}$ of previous dilution to $9 \mathrm{ml}$ of diluents (ISO 6888-1:1999. ISO, Geneva). Aseptically transfer $1 \mathrm{ml}$ sample suspension to plates of Baird Parker Agar and Spread inoculums over the agar surface using sterile bent glass rod. After 10 to 15 minutes, invert the plates and incubate at $35^{\circ} \mathrm{C}$ for 48 hours. Select characteristic colonies (Black, gray, smooth, circular, convex, moist colony with opaque.

\subsubsection{Culture method of Listeria monocytogenes}

$25 \mathrm{gm}$ of sample was added in $225 \mathrm{ml}$ of fraser broth with reduced concentration of selective agents at $30^{\circ} \mathrm{C}$ for $24 \pm 2 \mathrm{~h}$. then $0.1 \mathrm{ml}$ of the primary enriched sample is transferred in fraser broth with full concentration of selective agent Fraser broth and incubate at $35^{\circ} \mathrm{C}$ for $48 \pm 2 \mathrm{~h}$ (ISO 11290-1. ISO, Geneva). then from the primary selective medium one lop full of culture is streaked in Oxford agar and from the secondary selective medium one lop full of culture is streaked in PALCUM agar and incubate at $35^{\circ} \mathrm{C}$ for $48 \pm 2 \mathrm{~h}$. typical colonies of Listeria spp. grown in Oxford agar are grayish colonies surrounded by black halos and in PALCUM agar colonies are pink to purple color sometimes black centered an always black halos. After that Listeria spp. was confirmed by performing several appropriate biochemical tests.

\subsubsection{Culture method of yeast and mold}

The total yeast and mold count of the collected dairy products are enumerated according to ISO 21527-2:2008: Microbiology of food and animal feeding stuffs. Horizontal method for the enumeration of yeasts and molds. Part-2 colony count technique in products with high water activity.

\section{Results and Discussion}

\subsection{Total viable bacterial count (TVBC) and total coliform count (TCC)}

The most important hygienic indicator for food and food stuffs is total microbial load of the samples. Total Viable Bacterial Count of the number of bacteria which were present in samples were presented in Figures 1, 2 and 3. All the dairy products had high Microbial load ranged in between $5.90 \times 10^{5} \mathrm{cfu} / \mathrm{ml}$ to $8.97 \times 10^{9} \mathrm{cfu} / \mathrm{ml}$ which is much higher than the acceptable level suggested by BSTI and USPHS (Bangladesh Standards and Testing Institution. 2002. Bangladesh standard: Specification for pasteurized milk and Jay 2003). In other study the bacterial count in milk samples were from $7.5 \times 10^{7}$ to $1.24 \times 10^{8} \mathrm{cfu} / \mathrm{ml}$ (Hossain et al., 2010). One of the members of coliform bacteria Escherichia coli in dairy products is a common indicator of fecal contamination, this point out the hygienic standard and the storage quality of the milk product, rather than the presence of human pathogens. During the production, handling and storage of the dairy products extra precaution is necessary in order to lower the coliform count. Figure-1, 2 and 3 indicate Total coliform count in milk based 
product, the highest the coliform count was found in Borhani and Labang whereas the lowest was in Yogurt especially in Sour Yogurt this is because Yogurt have lower water activity then Borhani and Labang as well as cultured dairy products have low $\mathrm{pH}$ which is $\mathrm{pH}$ of 4.5 or less, this prevents the growth of most pathogenic and spoilage organisms which require $\mathrm{pH} 7$ for growth (Richter et al., 1992). Coliforms were found up to $10^{9}$ dilutions in milk based drink products Borhani and Labang sold in various areas can be considered as an unhygienic food in terms of coliform count and can a serious threat to the public health.

\subsection{Average count of yeast and mold in dairy products}

The total yeast \& molds count is another indicator for food hygiene and the results found in the collected samples devastatingly serious as molds are responsible for aflatoxinic contamination. The mold contamination was much lower in Borhani and Labang in between $7.46 \times 10^{4} \mathrm{cfu} / \mathrm{mlto} 7.54 \times 10^{5} \mathrm{cfu} / \mathrm{ml}$ on the other hand $7.86 \times 10^{8} \mathrm{cfu} / \mathrm{ml}$ number of mold was found in Yogurt which crosses the normal level, the reason of much higher mold contamination in Yogurt may be because of low $\mathrm{p}^{\mathrm{H}}$ which is around $\mathrm{p}^{\mathrm{H}} 5$ and perfect for molds. Interestingly, no yeast was found in any of the dairy products (Figure 4).

Table 1. Summery of biochemical test of E. coli, Salmonella spp., Shigella spp., Staphylococcus spp. and Listeria spp.

\begin{tabular}{|c|c|c|c|c|c|c|c|c|c|c|c|c|c|c|}
\hline Oroanism & & TSI & & $\stackrel{\pi}{=}$ & 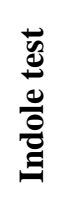 & 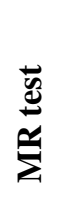 & $\frac{\overrightarrow{\underline{s}}}{\vec{b}}$ & 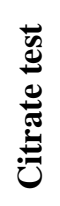 & 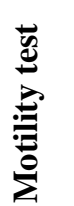 & 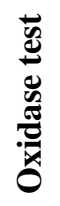 & 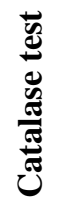 & 苞 & 志 & $\begin{array}{l}\text { 馬 } \\
\text { 馬 }\end{array}$ \\
\hline Organism & $\mathbf{S}$ & B & $\mathbf{G}$ & & & & & & & & & & & \\
\hline E. coli & $\mathbf{Y}$ & $\mathbf{Y}$ & + & - & + & + & - & - & + & - & + & - & - & - \\
\hline Salmonella & $\mathbf{R}$ & $\mathbf{Y}$ & - & + & - & + & - & - & + & - & + & - & - & - \\
\hline Shigella & $\mathbf{R}$ & $\mathbf{Y}$ & + & - & $+/-$ & + & - & - & - & + & + & - & - & - \\
\hline Staphylococcus & $\mathbf{Y}$ & $\mathbf{R}$ & + & - & - & + & - & + & - & - & + & - & - & - \\
\hline Listeria spp. & $\mathbf{Y}$ & $\mathbf{Y}$ & - & - & - & + & + & - & + & - & + & - & - & - \\
\hline
\end{tabular}

TSI = Triple Sugar Iron Test, Y = Yellow (Acidic), R = Red (Alkaline), MR = Methyl Red, VP= Voges - Proskauer

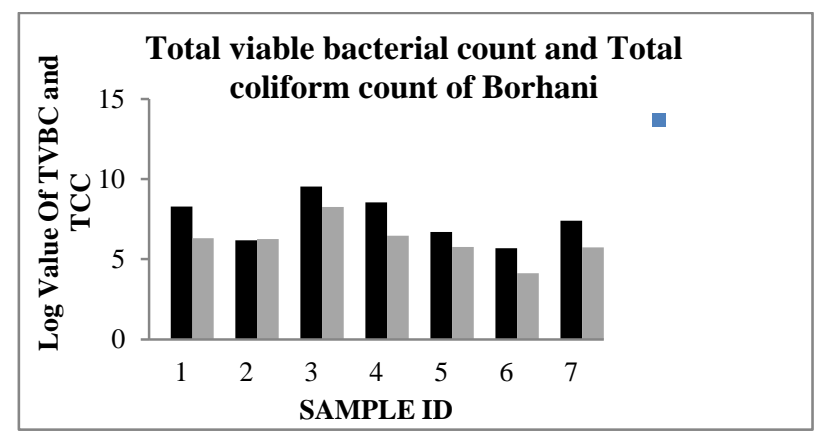

Figure 1. Total viable bacterial count and Total coliform count of Borhani.

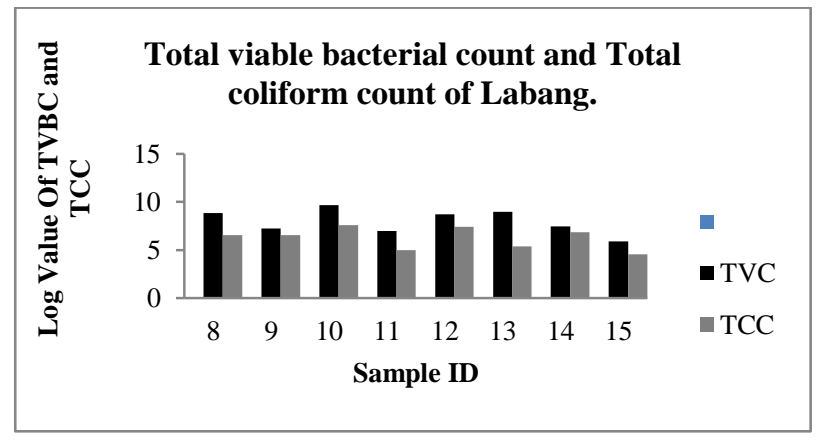

Figure 2. Total viable bacterial count and Total coliform count of Labang. 


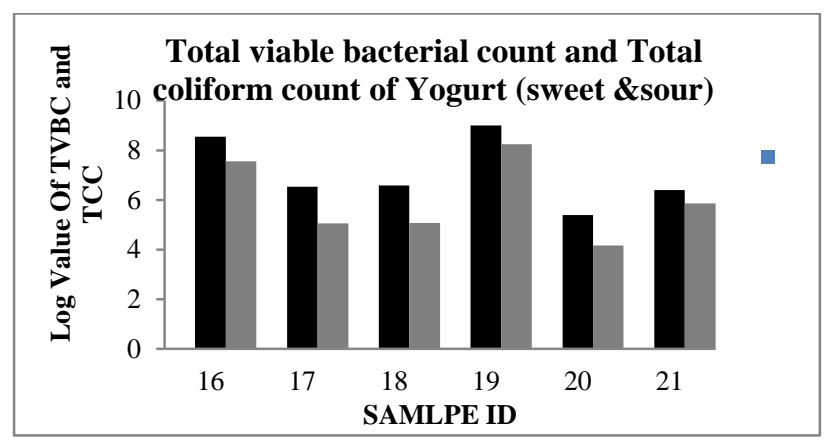

Figure 3. Total viable bacterial count and Total coliform count of Yogurt.

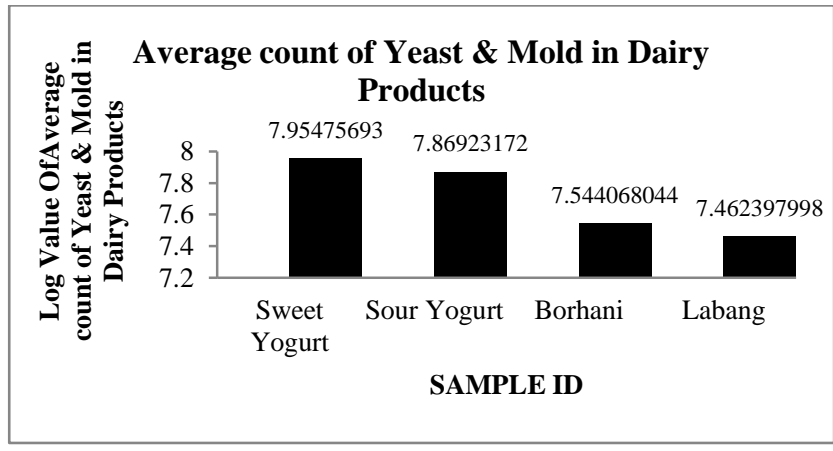

Figure 4. Average count of Yeast \& Mold in Dairy Products.

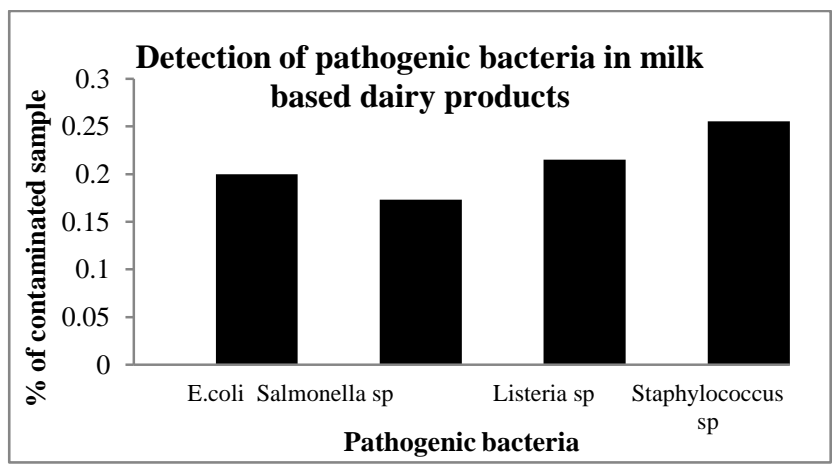

Figure 5. Detection of pathogenic bacteria in milk based dairy products.

\subsection{Presence of other pathogenic bacteria}

Some specific bacteria which are major food-borne pathogens including Salmonella spp., Staphylococcus spp., Listeria spp. and Shigella spp. (Kulshrestha, 1990) were cultured. The most common bacterial food infection caused by Salmonella spp. (Barro et al., 2002). Moreover, the ingestion of Salmonella contaminated food can cause typhoid fever and paratyphoid fever (Bhan and Bhatnagar, 2005) alongside the typical food-poisoning salmonellosis. Approximately $17 \%$ dairy products were contaminated by Salmonella spp. Another most frequently occurring food poisoning incidence is caused by the consumption of some specific strains of Staphylococcus aureus responsible for the formation of enterotoxin formed in food, if there is a possibility of public health issues because of Staphylococcus spp., it is better to test for enterotoxins (Richter et al., 1992). Majority of the dairy products (25.537\%, Figure 5) such as Yogurt, Borhani and Labang were contaminated by Staphylococcus spp., the enumeration of coagulase positive Baird-Parker agar (BPA, Oxoid) (ISO 6888-1:1999) was use for cultivation, coagulase and enterotoxins test it is worth to be mention that small number of dairy product samples were coagulase and enterotoxin positive. The presence of Listeria monocytogenes can be found in a wide range of raw and processed foods including milk and dairy products (Rocourtand Cossart, 1997) and the highest Listeria monocytogenes contamination was found in Yogurt, 7out of $21(21.515 \%)$ samples were contaminated. A minor number of milk based products were corrupted by Shigella spp. 


\subsection{Biochemical results for confirmation of dairy pathogens}

For confirmation, biochemical tests were done for every pathogenic bacteria species. All pathogenic bacteria were unable to hydrolyzed Urea, Gelatin, Starch as well as MR test. E. coli and Salmonella spp. were capable of degrading Glucose, Sucrose, Lactose and Maltose, no pathogen except Staphylococcus spp. was able to degrade Manitol. Kliger's Iron Test was also done only for E. coli and Salmonella spp. where slant and butt was acidic, no H2S gas formed for E. coli whereas slant was alkali and butt was acidic, H2S gas formed for Salmonella spp. (Table 1). Some additional Biochemical Tests were also performed for identification of enterotixin producing Staphylococcus spp. those are Coagulase production, Thermonuclease production, Lysostaphin sensitivity, Anaerobic utilization of glucose, mannitol and give positive reactions for all those Biochemical Tests (Biochemical results for Staphylococcus spp. are not shown in this study).

\section{Conclusions}

The findings of this present study shown, heavy microbial load and coliform contamination in the dairy product samples collected from different point of Dhaka city which exceeded the microbiological acceptation level of dairy product. Other pathogenic bacteria such as Salmonella spp., Shigella spp., Staphylococcus spp., and Listeria monocytogenes were also detected in several dairy products, indicate the hygiene quality of the samples were really poor. This will aware the public health department to improve and monitor the standard regulation and the quality of dairy products. Also Dhaka City Corporation (DCC) should arrange training and educational program for the producer of dairy product so that they can improve their food handling practices, minimum requirements of good hygienic and sanitary conditions and good storage conditions to reduce the risk microbiological contamination. The regulatory bodies should enact specific laws, legislations, rules and guidelines for production of dairy products to control microbiological quality, adulteration, sanitation and quality assurance of these products.

\section{Conflict of interest}

None to declare.

\section{References}

Aneja RP, BN Mathur, RC Chandan and AK Banerjee, 2002. Technology of Indian Milk Products; A Dairy India Publication, Delhi.

Bangladesh Standards and Testing Institution, 2002. Bangladesh standard: specification for pasteurized milk. Bangladesh Standards and Testing Institution, Tejgaon Industrial Area, Dhaka.

Barro N, CA Ouattara, PA Nikiema, AS Ouattara, and AS Traore, 2002. Microbial quality assessment of some street food widely consumed in Ouagadougou, Burkina Faso. Sante 12, 369-374.

Bhan MK, R Bahl and S Bhatnagar, 2005. Typhoid and paratyphoid fever. Lancet, 366: 749-762.

European Commission, 2003. Commission recommendation of 19 December 2003 concerning a coordinated programme for the official control of foodstuffs for 2004 (2004/24/EC). Official Journal of the European Union 2004; L6:29-37.

European Commission, 2005. Commission recommendation of 1st March 2005 concerning a coordinated programme for the official control of foodstuffs for 2005 (2005/175/EC). Official Journal of the European Union 2005; L59:27-39.

Haq JA and KM Rahman, 1991. Campylobacter jejuni as a cause of acute diarrhoea in children: a study at an urban hospital in Bangladesh. J. Trop. Med. Hyg., 94: 50-54.

Henry FJ, SRA Huttly, Y Patwary and KMA Aziz, 1990. Environmental sanitation, food and water contamination and diarrhoea in rural Bangladesh. Epidemiol. Infect., 104: 253-259.

Hossain TJ, K Alam and D Sikdar, 2010. Chemical and microbiological quality assessment of raw and processed liquid market milks of Bangladesh. Res. J. Dairy Sci., 4: 28-34.

International Organization for Standardization (ISO), 2003. Microbiology of food and animalfeeding stuffsHorizontal method for the enumeration of microorganisms - Colony count technique at $30^{\circ}$ C.ISO 4833:2003. Geneva.

International Organization for Standardization (ISO), 2004. Microbiology of food and animal feeding stuffsHorizontal method for the detection of Shigella sp. ISO 21567:2004, Geneva.

International Organization for Standardization (ISO), 1996. Microbiology of food and animal feed - horizontal method for the detection and enumeration of Listeria monocytogenes and other Listeria species-Part 1: Detection method. ISO 11290-1. ISO, Geneva. 
International Organization for Standardization (ISO), 1999. Microbiology of food and animal feeding stuffshorizontal method for the enumeration of coagulase-positive staphylococci (Staphylococcus aureus and other species)—Part 1: Technique using Baird-Parker agar medium. ISO 6888-1:1999. ISO, Geneva.

International Organization for Standardization (ISO), 2002. Microbiology of food and animal feeding stuffshorizontal method for the detection of Salmonella spp. ISO 6579:2002 + A 1:2007. ISO, Geneva.

International Organization for Standardization (ISO), 2006. Microbiology of food and animal feeding stuffshorizontal method for the detection and enumeration of coliforms - most probable number technique. ISO 4831:2006. ISO, Geneva.

International Organization for Standardization (ISO), 2009. Microbiology of food and animal feeding stuffs. Horizontal method for the detection and enumeration of E. coli- Most probable Number technique. ISO 7251:2009. ISO, Geneva.

Islam MS, MK Hasan and SI Khan, 1993. Growth and survival of Shigella flexneri in common Bangladeshi foods under various conditions of time and temperature. Appl. Environ. Microbiol., 59: 652-654.

Huisin't Veld JHJ, 1996. Microbial and biochemical spoilage of foods: an overview. Int. J. Food Microbiol., 33: $1-18$.

Jay JM, 2003. Modern Food Microbiology, 4th ed. CBS Publishers and Distributor, India.

Kulshrestha SB, 1990. Prevalence of enteropathogenicsero groups of E. coli in milk products samples from Bareilly and their multiple drug resistance. Indian J. Dairy Sci., 43: 337-378.

Luby SP, M Rahman, MJ Hossain, LS Blum, MM Husain, E Gurley, R Khan, B Ahmed, S Rahman, N Nahar, E Kenah, JA Comer and TG Ksiazek, 2006. Foodborne transmission of Nipah virus, Bangladesh. Emerg. Infect. Dis., 12: 1888-1894.

Rajagopal M, BG Werner and JH Hotchkiss, 2005. Low pressure CO2 storage of raw milk: microbiological effects. J. Dairy Sci., 88: 3130-3138.

Marjan S, KK Das, SK Munshi and R Noor, 2014. Drug-resistant bacterial pathogens in milk and some milk products. Nutn. Food Sci., 44: 241-248.

Vasavada PC, 1993. Rapid methods and automation in dairy microbiology. J. Dairy Sci., 76: 3101-3113.

Ruegg PL, 2003. Practical food safety interventions for dairy production. J. Dairy Sci., 86: E1-E9.

Richter RL, RA Ledford and SC Murphy, 1992. Compendium of Methods for the Microbiological Examination of Foods C. Vanderzant and D.F. Splittstoesser (eds.) 3rd ed. (American Public Health Association, Washington DC), Chap. 45, pp. 837-856.

Ram PK, A Naheed, WA Brooks, MA Hossain, ED Mintz, RF Breiman and SP Luby, 2007. Risk factors for typhoid fever in a slum in Dhaka, Bangladesh. Epidemiol. Infect., 135: 458-465.

Rocourt J and P Cossart, 1997. Listeria monocytogenes. In Food Microbiology-Fundamentals and Frontiers, Doyle MP, Buechat LR, and Montville TJ (eds.), pp. 337-352. American Society for Microbiology Press, Washington DC.

Tatini SR and KL Kauppi, 2003. Encyclopedia of Dairy Sciences H. Roginski, J.W. Fuquay and P.F. Fox (eds.) Vol. 1. Academic Press and Elsevier Science, Amsterdam, Boston, London, New York, Oxford, Paris, San Diego, San Francisco, Singapore, Sydney, Tokyo, pp. 74-79.

Saha SK, S Saha, S Shakur, M Hanif, MA Habib, SK Datta and HL Bock, 2009. Community-based crosssectional seroprevalence study of hepatitis A in Bangladesh. World J. Gastroenterol., 15: 4932-4937.

Sheikh A, M Sugitani, N Kinukawa, M Moriyama, Y Arakawa, K Komiyama, TC Li, N Takeda, SM Ishaque, M Hasan and K Suzuki, 2002. Hepatitis e virus infection in fulminant hepatitis patients and an apparently healthy population in Bangladesh. Am. J. Trop. Med. Hyg., 66: 721-724.

Uddin MA, HMMU Haque and R Noor, 2011. Isolation and Identification of pathogenic Escherichia coli, Klebsiella spp. and Staphylococcus spp. in raw milk samples collected from different areas of Dhaka city, Bangladesh. Stamford J. Microbiol., 1: 19-23.

World Health Organization (WHO), 1999. Food Safety: An Essential Public Health Issue for the New Millennium. Food Safety Programme, Department of Protection of the Human Environment, Cluster of Sustainable Development and Healthy Environments, WHO, Geneva. 